РОЗДІЛ 3

РОМАНСЬКІ МОВИ

УДК 373.3/.5.016:811.12]:005.953.2

DOI https://doi.org/10.32782/tps2663-4880/2021.20.2.13

\author{
РОЗВИТОК МІЖКУЛЬТУРНОЇ КОМУНІКАТИВНОЇ КОМПЕТЕНТНОСТІ \\ В УЧНІВ ФІЛОЛОГІЧНОГО ПРОФІЛЮ \\ (НА МАТЕРІАЛІ ІТАЛІЙСЬКИХ ПІСЕНЬ)
}

\title{
DEVELOPMENT OF INTERCULTURAL COMMUNICATIVE COMPETENCE OF STUDENTS WITH ADVANCED LEARNING OF FOREIGN LANGUAGES (ON THE MATERIAL OF ITALIAN SONGS)
}

\author{
Харченко Т.Г., \\ orcid.org/0000-0002-4480-1585 \\ доктор педагогічних наук, доиент, \\ професор кафедри романської філологї та порівняльно-типологічного мовознавства \\ Киїського університету імені Бориса Грінченка \\ 3ix O.E., \\ orcid.org/0000-0003-0163-733X \\ здобувачка другого освітнього рівня (магістерського) освітньої програми \\ «Мова і література (італійська)» \\ Київського університету імені Бориса Грінченка
}

\begin{abstract}
У статті доведено, що міжкультурна комунікативна компетентність є найважливішим складником під час підготовки учнів до міжкультурної комунікації. ІЇ̈ розвиток вимагає шукати та створювати нові засоби навчання, які могли б мотивувати учнів. Відсутність дидактичних матеріалів, адаптованих під учнів, які не є носіями мови, забирає можливість набуття соціокультурних знань про країну, звички людей і культуру, мову якої вони вивчають. 3 метою розвитку соціокультурних і комунікативних компетентностей учнів розроблено навчальний посібник «Вчимо італійську мову за популярними піснями!». Збірник $є$ практичним посібником для поглиблення знань у лексиці та граматиці італійської мови. Видання доповнене автентичними італійськими піснями по всім темам, що вивчаються. Структура посібника містить в собі вправи за 5 тематичними блоками: «Tutti a tavola» (Усі за столом); «Professione e specialità» (Профресії та спеціальності); «L'Italia. Grandi città» (Італія. Великі міста); «Mass Media. II cellulare nella nostra vita» (Масмедіа. Телефон у нашому житті); «Emozioni nella nostra vita» (Наші емоції). У статті описано методичний експеримент, організований з метою перевірки ефективності розробленої системи вправ з фрормування міжкультурної комунікативної компетентності в учнів філологічного профілю зі збірника «Вчимо італійську мову за популярними піснями!». Сформульовано гіпотезу експерименту, описано його етапи, проаналізовано зміст і завдання переді післяекспериментального зрізів. Представлено результати експериментальних зрізів, які підтвердили загальну ефективність розробленої системи вправ. Доведено, що розробка сучасних цікавих засобів навчання для вивчення італійської мови - це першочергове завдання для популяризації цієї іноземної мови в Україні.
\end{abstract}

Ключові слова: аутентичні тексти, італійська мова, мовні знання, профільна школа, соціокультурна компетентність.

The article confirms that intercultural communicative competence is the most important component in preparing students for intercultural communication. Its development requires the search and creation of new teaching aids that could motivate students. The lack of didactic materials adapted for students who are not native speakers takes away the opportunity to acquire socio-cultural knowledge about the country, people's habits and culture, the language of which they are studying. With the aim of developing the socio-cultural and communicative competences of students, a practical manual "Вчимо італійську мову за популярними піснями!" has been developed. The collection is a practical guide to deepening knowledge in the vocabulary and grammar of the Italian language. The publication is supplemented with authentic Italian songs on all topics studied. The structure of the manual includes exercises in 5 thematic blocks: "Tutti a tavola" (Everyone at the table); "Professione e specialità" (Profession and specialty); "L'Italia. Grandi città" (Italy. Big cities); "Mass Media. II cellulare nella nostra vita" (Mass Media. The mobile phone in our life); "Emozioni nella nostra vita" (Emotions in our life). The article outlines a methodical experiment organized to test the effectiveness of the developed system of exercises for the formation of intercultural communicative competence of students of philological profile in the manual "Вчимо італійську мову за популярними піснями!". The hypothesis of the experiment is formulated, its stages are described, the content and tasks of pre- and post-experimental sections are analyzed. The results of experimental sections are presented, which confirmed the overall effectiveness of the developed system of exercises. It is proved that the development of modern interesting teaching aids for learning Italian is a priority for the promotion of this foreign language in Ukraine.

Key words: authentic texts, socio-cultural competence, foreign language communicative competence, Italian language, linguistic knowledge, specialized schools. 
Постановка проблеми. Метою сучасної освіти в галузі навчання іноземних мов $є$ розвиток вторинної мовної особистості, здатної реалізувати себе в межах діалогу культур, в умовах міжкультурної комунікації. Така стратегія передбачає пошук ефективних шляхів взаємопов'язаного комунікативного й соціокультурного розвитку. На наш погляд, одним із таких методичних рішень створення реального міжкультурного спілкування $є$ робота на уроках іноземної мови 3 автентичними піснями. Ми зосередили свою увагу на вивченні потенціалу аутентичних пісень у процесі підготовки учнів профільної школи до міжкультурної комунікації, оскільки вважаємо, що пісня $\epsilon$ важливим елементом будь-якої мови, адже через неї ми можемо не лише зацікавити вивченням і вмотивувати учня до вивчення іноземної мови, а й познайомитися з культурою країни, мову якої ми вивчаємо.

Аналіз останніх досліджень і публікацій. Аналіз наукових досліджень показав, що різні аспекти проблеми формування міжкультурної комунікативної компетентності досліджують такі сучасні українські дослідники, як О. Бігич, Г. Борецька, Н. Бориско, Н. Майер, С. Ніколаєва, Т. Олійник, М. Писанко, Л. Сажко, Н. Скляренко, С. Смоліна, I. Соболєва, О. Устименко, Е. Хоменко, Н. Христич, В. Черниш, С. Шукліна й ін. Вивченням питання про особливості формування соціокультурної компетентності в процесі навчання іноземної мови в різні часи займалися Є. Верещагін, Н. Коряковцева, В. Костомаров, Н. Саланович, В. Сафонова, Г. Томахин та ін. Проблема використання пісенного матеріалу в ході вивчення іноземної мови розкрита в роботах В. Кузовлева, Н. Кулахметової, Е. Маслико, Е. Пассова, В. Царькова. У роботах учені вказують на те, що використання пісенного матеріалу це ефективна форма роботи, яка наближає учнів до реального використання мови, допомагає адаптуватися до розуміння культури, ознайомлює 3 лінгвістичними засобами, підвищує комунікативно-пізнавальну мотивацію.

Проте, незважаючи на накопичені значні теоретичні здобутки, на наш погляд, українській лінгводидактиці бракує практичних розробок 3 досліджуваної проблеми. Актуальність дослідження підсилюється тим, що недостатньо уваги приділено розробці навчально-методичних видань саме з італійської мови. У зв'язку з цим автори статті розробили навчальний посібник «Вчимо італійську мову за популярними піснями!», який може використовуватися як на уроках італійської мови в профільній школі, так і для самостійної роботи учнів [1].
Постановка завдання. Метою статті $€$ теоретичне обгрунтування, практична розробка й експериментальна перевірка методики формування італійськомовної комунікативної міжкультурної компетентності в учнів філологічного профілю 3 використанням автентичних пісень. Мета статті передбачає виконання таких завдань дослідження: вивчення й аналіз праць із проведення експериментального навчання; визначення гіпотези; опис проведення передекспериментального зрізу, експериментального навчання та післяекспериментального зрізу, аналіз та інтерпретація отриманих результатів.

Виклад основного матеріалу. Ми поділяємо думку видатного дослідника сучасної італійської лінгводидактики А. Комоді, що автентичні аудіоматеріали дають змогу розвивати фонологічну, лексичну, семантичну, граматичну, морфологічну, синтаксичну, а також прагматичну компетентності, які допомагають учневі «сприймати глобальний сенс повідомлення й здобувати реальну прагматично-функціональну компетенцію італійської мови» [6, с. 14]. Автентичні пісні полегшують процес акультурації. «Використання справжніх матеріалів як живе й безпосереднє свідчення італійської культури й цивілізації та пов'язаних із ними проявів виявилося надзвичайно корисним для направлення учня до приємного відкриття італійської мови й культури, отже, до кращого самопізнання» $[6$, с. 10]. Автентичні пісні стимулюють мотивацію учнів до вивчення іноземної мови, полегшують запам'ятовування іншомовного матеріалу, сприяють його повторенню, стимулюють розпізнавання й вироблення мовних ритмів, сприяють появі інтерактиву в класі, демонструють елементи культури й учать їх.

Якщо ми говоримо про учнів як про адресатів музичного матеріалу, ми повинні орієнтуватися на їхні попередні знання, зважаючи не тільки на рівень сформованості іншомовної лексичної компетентності, а й на глибину їхньої культурної обізнаності. Було б важко без попереднього знання сучасних подій навіть для просунутих учнів зрозуміти тонкий сарказм пісні, у якій використовується гра слів (la pinza nella panza, la pizza e il pizzo), або риторичні фігури й іронічні послання, як у пісні Сан-Ремо “Рараveri e papi”.

Тому в розробленому нами посібнику ми зосередили увагу на учнях старших класів, тому що саме в підлітковому віці розвиваються словесно-логічне мислення, монологічне, діалогічне й писемне мовлення, відбувається становлення довільності пізнавальних процесів, вироблення індивідуального стилю інтелектуальної діяльно- 
сті. Саме тому серед найефективніших завдань на уроках іноземної мови в 10-11-х класах може бути створення діалогів, пов'язаних з іншомовними реаліями, розігрування різноманітних ситуацій після прослуховування автентичних текстів (пісень), типових для культури країни, мова якої вивчається [8]. Для учнів філологічного профілю, які поглиблено вивчають італійську мову, ми відібрали пісні з ускладненою граматикою і синтаксисом, а також регіональною вимовою, швидким ритмом, багатою лексикою і більш складними темами.

Розроблений збірник є практичним посібником для поглиблення знань про життя й культуру Італії, розвитку лексичної й граматичної компетенцій. Видання доповнене автентичними італійськими піснями по всіх темах, що вивчаються. Структура посібника містить вправи за 5 тематичними блоками: "Tutti a tavola" (Усі за столом); "Professione e specialità" (Професії та спеціальності); "L'Italia. Grandi città" (Італія. Великі міста); "Mass Media. Il cellulare nella nostra vita" (Масмедіа. Телефон у нашому житті); "Emozioni nella nostra vita" (Наші емоціi).

3 метою визначення ефективності розробленої системи вправ для формування міжкультурної комунікативної компетентності в учнів філологічного профілю нами проведено експериментальне дослідження, яке потребувало від нас комплексної підготовки на всіх етапах роботи.

На першому підготовчому етапі експерименту сформульовано гіпотезу дослідження, визначено мету й основні завдання експерименту, розроблено інструментарій і проведено підготовчі роботи. За основу експериментального дослідження рівня сформованості італійськомовної міжкультурної компетентності учнів філологічного профілю взято припущення, що ефективність формування елементів зазначеної компетентності підвищується за рахунок використання автентичних пісень на уроках італійської мови.

Для досягнення мети дослідження передбачено розв'язання таких завдань: з'ясувати ступінь зацікавленості учнів при роботі з автентичними піснями; визначити рівень сформованості італійськомовної міжкультурної компетенції в учнів профільного навчання на початковому й фінальному етапах; дослідити та проаналізувати ефективність розроблених навчальних матеріалів, що спрямовані на розвиток іншомовної міжкультурної компетентності в учнів 10-11-х класів філологічного профілю, які в роботі використовують пісенний автентичний матеріал.

Під час підготовки до проведення експерименту ми підібрали пісенний матеріал за темами та розробили низку вправ, спрямованих на формування італійськомовної міжкультурної компетентності в учнів філологічного профілю. Усі розроблені навчальні матеріали стали основою навчального посібника «Вчимо італійську мову за популярними піснями!» [1]. При підготовці до проведення експерименту нами розроблено вправи для проведення передекспериментального зрізу знань учнів.

На другому основному етапі була визначена методика проведення експериментального дослідження. Воно проходило з 8 березня 2021 року і продовжувалося до 2 травня 2021 року в спеціалізованій школі № 130 ім. Данте Аліг’єрі $з$ поглибленим вивченням англійської та італійської мов міста Києва. Експеримент проходив в 11-му класі. Проте варто зазначити, що через епідемію COVID-19 для запобігання захворюваності серед учнів навчання проходило дистанційно. Для прозорості експерименту учні були поділені на експериментальну та контрольну групи.

У ході дослідження ми отримали рекомендації та коментарі від учителя італійської мови, який безпосередньо працює 3 учнями, і взяли їх до уваги під час складання якісної характеристики учнів. В експериментальну групу входило 10 учнів із середнім балом 9,2, тоді як у контрольну групу входило 9 учнів із середнім балом 9,7.

На першому занятті учням було запропоновано пройти анкетування, яке допомогло нам зрозуміти рівень сформованості в учнів міжкультурної компетентності та їхне ставлення до використання пісенного автентичного матеріалу на уроках італійської мови. В опитуванні взяли участь 19 учнів. На перше запитання «Чи маєте Ви досвід роботи 3 піснями на уроках з іноземної мови?» 11 учнів $(57,9 \%)$ відповіли «Рідко», 6 учнів $(31,6 \%)$ - «Так», 2 учні $(10,5 \%)-\langle\mathrm{Hi} » . \mathrm{Ha}$ друге запитання «Чи подобається вам працювати iз піснями на уроках з італійської мови?» 16 учнів $(84,2 \%)$ дали відповідь «Так», 3 учні $(15,8 \%)-$ «Ні». На наступне запитання «Які труднощі виникають у вас, коли ви виконуєте завдання, що передбачають попереднє прослуховування пісні?» 10 учнів (52,6\%) відповіли, що «Труднощів немає», 6 (31,6\%) - «Важко перекласти слова, які $\epsilon$ в пісні», 3 учні (15,8\%) - «Пісні занадто швидкі, через що не вистачає часу зрозуміти, як виконати завдання». На четверте запитання опитування «Чи сформовані у вас соціокультурні знання, які дають змогу вам вільно спілкуватися з іноземцями?» 11 учнів $(57,9 \%)$ відповіли «Недостатньо сформовані», 5 учнів $(26,3 \%)$ - «Так», 3 учні $(15,8 \%)$ відповіли «Зовсім не сформовані». На 
заключне п’яте запитання анкети «Чи допомагають вам пісні у вивченні нового лексичного матеріалу та чи допомагають у розширенні соціокультурних знань?» 13 учнів $(68,4 \%)$ відповіли «Так», 5 учнів (26,3\%) - «Важко відповісти», 1 учень $(5,3 \%)-« \mathrm{Hi} »$.

Після аналізу отриманих відповідей ми можемо зрозуміти, що учням цікаво працювати на уроках 3 автентичними піснями, вони допомагають їм у засвоєнні іншомовного матеріалу. Учні позитивно сприймають невідомі для них нові види роботи 3 піснями на уроках іноземної мови. Вони мають засвоєні навички й уміння, що є необхідними для засвоєння матеріалу на слух. Проте, коли матеріал ускладнений лексично чи фонетично, в учнів виникають труднощі, що можуть заважати формуванню соціокультурних і комунікативних знань.

Під час реалізації основного етапу експерименту ми провели два типи зрізів: передекспериментальний i післяекспериментальний. Їх результати допомогли зрозуміти, чи є доцільним використання розробленої методики в процесі підготовки учнів до міжкультурної комунікації.

Проведення передекспериментального зрізу мало на меті визначити початковий рівень сформованості в учнів італійськомовної міжкультурної компетентності, їх здатності сприймати на слух автентичні італійськомовні аудіотексти.

Експериментальній і контрольній групі було запропоновано прослухати автентичну італійську пісню й виконати вправи після прослуховування. Для цього завдання була обрана пісня, яка відповідає рівню знань В2, «Tutta mia la città», автором якої є Джуліано Пальма.

Учням було запропоновано виконати вправи на знаходження пропущених слів, граматичні вправи, тести на розуміння лексики та вправи на побудову власного висловлення.

В експерименті для об'єктивного відображення рівня сформованості італійськомовної міжкультурної компетентності ми вирішили відобразити результати передекспериментального та післяекспериментального зрізів за допомогою коефіцієнта навченості. Формула для його визна- чення була розроблена В. Безпальком: $\mathrm{K}=\mathrm{Q} / \mathrm{N}$ (де К - коефіцієнт навченості, Q - загальна кількість балів, яку отримано в ході виконання завдання; N - максимальна кількість балів із можливих) [2, с. 52-69]. За сучасною системою оцінювання, 12 балів - це максимальна оцінка. Варто зауважити, що максимальний коефіцієнт успішності становить 1, а мінімальний, у свою чергу, $-0,7$. Пропонуємо розглянути результати передекспериментального зрізу.

Отже, результати проведеного передекспериментального зрізу засвідчили, що середній коефіцієнт контрольної групи становить 0,8, а коефіцієнт експериментальної групи - 0,76. Ми можемо сказати, що показники у двох групах схожі, проте середній коефіцієнт наближений до мінімально достатнього. Ці результати зумовлюють потребу використання розробленого нами збірника завдань із піснями.

Тому ми перейшли до дослідження висунутої нами гіпотези та почали підготовку безпосередньо до експериментального навчання. Навчання відбувалося паралельно в експериментальній i контрольній групах. Усього було проведено по 4 заняття в кожній. Для об'єктивності й точності результатів ми вирішили «зрівняти сили» двох груп. Тобто в групі, яка має нижчий середній бал, в нашому випадку це експериментальна група, ми запропонували розроблені нами уроки. Водночас контрольна група продовжувала навчатися за матеріалами, які використовує шкільний учитель зазвичай. Метою цього кроку було побачити різницю в успішності двох груп, особливості розвитку їхніх лексичних і граматичних навичок, уміння комунікувати на поставлену тему. Результати післяекспериментального зрізу наведено в таблиці нижче.

Після отримання результатів ми побачили, що після проведення післяекспериментального зрізу середній коефіцієнт контрольної групи становить 0,81. Коефіцієнт експериментальної групи виріс і становить 0,84. Тобто експериментальна група, яка від самого початку мала менші показники, вибилася і лідери та показала кращий результат.

Таблиця 1

Середні показники коефіцієнта навченості учнів за результатами передекспериментального зрізу

\begin{tabular}{|c|c|c|c|c|}
\hline \multirow{2}{*}{ Група } & \multicolumn{2}{|c|}{ Отримані бали } & Середній бал & $\begin{array}{c}\text { Середній коефіцієнт } \\
\text { навченості }\end{array}$ \\
\cline { 2 - 4 } & $\begin{array}{c}\text { Розуміння окремих } \\
\text { запитань }\end{array}$ & $\begin{array}{c}\text { Повнота розуміння } \\
\text { цілісного завдання }\end{array}$ & 9,80 \\
\hline КГ & 5,02 & 4,68 & 9,7 & 0,76 \\
\hline $\mathbf{E \Gamma}$ & 4,83 & 4,37 & 9,2 & 1 \\
\hline \multicolumn{7}{|c|}{ Максимальна кількість балів } \\
\hline
\end{tabular}


Таблиця 2

Середні показники коефіціснта навченості учнів за результатами післяекспериментального зрізу

\begin{tabular}{|c|c|c|c|c|}
\hline \multirow{2}{*}{ Група } & \multicolumn{2}{|c|}{ Отримані бали } & \multirow{2}{*}{ Середній бал } & $\begin{array}{c}\text { Середній коефіцієнт } \\
\text { навченості }\end{array}$ \\
\cline { 2 - 3 } & $\begin{array}{c}\text { Розуміння окремих } \\
\text { запитань }\end{array}$ & $\begin{array}{c}\text { Повнота розуміння } \\
\text { цілісного завдання }\end{array}$ & 9,74 & 0,81 \\
\hline КГ & 5,03 & 4,71 & 10,1 & 0,84 \\
\hline $\mathbf{E} \Gamma$ & 5,07 & 5,03 & 12 & 1 \\
\hline \multicolumn{5}{|c|}{ Максимальна кількість балів } \\
\hline
\end{tabular}

Таблиця 3

Порівняльні результати передекспериментального та післяекспериментального зрізів

\begin{tabular}{|c|c|c|c|}
\hline \multirow{2}{*}{ Група } & \multicolumn{3}{|c|}{ Коефіціснт навченості учнів } \\
\cline { 2 - 4 } & Передекспериментальний зріз & Післяекспериментальний зріз & Різниця даних \\
\hline КГ & 0,80 & 0,81 & 0,1 \\
\hline ЕГ & 0,76 & 0,84 & 0,8 \\
\hline
\end{tabular}

Ми вважаємо доцільним порівняти результати передекспериментального й післяекспериментального зрізів обох груп у таблиці.

Отже, ми бачимо, що приріст успішності контрольної групи становить усього 0,01 , тобто відібраний навчальний матеріал не сприяс успішному розвитку зазначених вище компетенцій. Приріст успішності в експериментальній групі становить 0,08 , що доводить нам, що використання на уроках розроблених нами вправ із авторського збірника завдань із піснями для формування італійськомовної міжкультурної комунікативної компетентності учнів профільної школи є доцільним та успішним.

Висновки. Відсутність розроблених навчально-методичних посібників із автентичними матеріалами, адаптованих для українських учнів, позначається на їхній успішності й мотивації до вивчення італійської мови. Матеріали, що використовуються на уроках, не завжди можуть розвинути в учнів здатність до міжкультурної комунікації, тому що необхідна навчальна інформація зазвичай подана безсистемно й у недостатній кількості.
Практика використання в навчальному процесі розробленого нами навчального посібника довела, що вживання автентичних пізнавально-розважальних пісень створює додаткову мотивацію до вивчення італійської мови, допомагає розвивати лексичні та граматичні знання, дає змогу учням комунікувати 3 носіями мови на різні теми й розуміти іншомовні контексти. Збірник завдань із піснями допомагає сформувати міжкультурну комунікативну компетентність, що сприяє засвоєнню знань про культуру, історію та особливості життя італійців. Ми радимо використовувати цей збірник для підготовки уроків 3 італійської мови для учнів профільних класів, а також використовувати його учням для самоперевірки набутих навичок і вмінь.

Здійснене дослідження не вичерпує всіх аспектів проблеми формування міжкультурної комунікативної компетентності в учнів філологічного профілю. Перспективи вбачаємо у створенні системи вправ і завдань із розвитку італійськомовної навчально-стратегічної компетентності в учнів старшої профільної школи.

\section{СПИСОК ВИКОРИСТАНИХ ДЖЕРЕЛ:}

1. Харченко Т., О. Зіх О. Вчимо італійську мову за популярними піснями : навчальний посібник. Від 28.09.2021 № 108254 .

2. Беспалько В.П. Слагаемые педагогической технологии. Москва : Педагогика, 1989. 192 с.

3. Вишневський О.І. Методика навчання іноземних мов : навчальний посібник. Київ : Знання, 2010. 206 с.

4. Загальноєвропейські рекомендації з мовної освіти: вивчення, викладання, оцінювання / за ред. С.Ю. Ніколаєвої. Київ : Ленвіт, 2003. 273 с.

5. Методика навчання іноземних мов: теорія і практика : підручник для студ. лінгв. ун-тів і фак. ін. мов вищ. навч. закладів / О.Б. Бігич та ін. ; за заг. ред. С.Ю. Ніколаєвої. Київ : Ленвіт, 2013. 590 с.

6. Comodi A. Materiali autentici: selezione e uso nella didattica dell'italiano come lingua straniera. Perugia : Guerra Edizioni. 1995. 32 p.

7. Marin T., Magnelli S. Nuovo progetto italiano 1. Libro dello studente. Edilingua. Roma, 2006. 198 p.

8. Sanders R.A. Adolescent psychosocial, social, and cognitive development. Pediatr Rev. 2013. 